\title{
PREDIKSI HARGA BERAS DI TINGKAT PERDAGANGAN BESAR INDONESIA MENGGUNAKAN ALGORITMA BACKPROPAGATION
}

\author{
Natasya ${ }^{1}$, S. Musdalifah², dan Andri ${ }^{3}$ \\ 1,2,3 Program Studi Matematika Jurusan Matematika FMIPA Universitas Tadulako \\ Jalan Soekarno-Hatta Km. 09 Tondo, Palu 94118, Indonesia. \\ 1natasyacaca22@gmail.com, 25selvymusdalifah@gmail.com, 33andri90@untad.ac.id
}

\begin{abstract}
Rice is one of the most consumed staples of Indonesian people and rice is not only a staple food but also an important source of nutrients in the food structure. In general, the price of rice in Indonesia's wholesale trade has increased from time to time, and from an economic point of view, the price of rice is an important aspect that needs attention, because if the price of rice continues to rise it can affect people's purchasing power and purchasing power. farmer production. Therefore, one way to find out the estimated retail price of rice is to make forecasts or predictions. The purpose of this study was to obtain the results of rice price predictions using the backpropagation method in 2021. This research was conducted using data on rice prices at the Indonesian wholesale trade level from January 2010 - December 2020. The data were used for the training process and the testing process, respectively. by $50 \%$. The level of accuracy obtained using MAPE reaches $0.54467 \%$ for training data and reaches $0.44262 \%$ for testing data.
\end{abstract}

Keywords : : Accuracy, Rice, Backpropagation, Prediction

\section{ABSTRAK}

Beras merupakan salah satu bahan pokok yang paling banyak dikonsumsi masyarakat Indonesia dan beras tidak hanya sebagai makanan pokok saja melainkan sebagai sumber nutrisi penting dalam struktur pangan. Pada umumnya harga beras di perdagangan besar Indonesia dari waktu ke waktu mengalami kenaikan, dan jika dilihat dari segi ekonomi, harga beras merupakan salah satu aspek penting yang perlu mendapatkan perhatian, karena jika harga beras terus naik hal tersebut dapat mempengaruhi pada daya beli masyarakat dan daya produksi petani. Oleh karena itu salah satu cara untuk mengetahui perkiraan harga eceran beras adalah dengan melakukan peramalan atau prediksi. Tujuan penelitian ini adalah untuk mendapatkan hasil prediksi harga beras menggunakan metode backpropagation pada tahu 2021. Penelitian ini dilakukan dengan menggunakan data harga beras di tingkat perdagangan besar Indonesia dari Januari 2010 - Desember 2020. Data tersebut digunakan untuk proses pelatihan dan proses pengujian yang masing-masing sebesar $50 \%$. Tingkat akurasi yang diperoleh menggunakan MAPE mencapai $0.54467 \%$ untuk data trainng dan mencapai $0.44262 \%$ untuk data testing.

Kata Kunci : Akurasi, Beras, Backpropagation, Prediksi 


\section{PENDAHULUAN}

Beras merupakan salah satu bahan pokok yang paling banyak dikonsumsi masyarakat Indonesia dan beras juga merupakan sumber nutrisi penting dalam struktur pangan. Untuk itu aspek penyediaan dan distribusi beras menjadi hal yang sangat penting mengingat jumlah penduduk Indonesia yang sangat besar dan menyebar di berbagai pulau yang ada.

Pada umumnya harga beras di perdagangan besar Indonesia dari waktu ke waktu mengalami kenaikan, dan jika dilihat dari segi ekonomi, harga beras merupakan salah satu aspek penting yang perlu mendapat perhatian, karena jika harga beras terus naik hal tersebut dapat mempengaruhi pada daya beli masyarakat dan daya produksi petani. Oleh karena itu salah satu cara untuk mengetahui perkiraan harga eceran beras adalah dengan melakukan peramalan atau prediksi.

Prediksi merupakan hal penting yang digunakan untuk mengetahui kejadian di masa mendatang dengan mengenali pola kejadian dimasa lampau. Dengan mengetahui kejadian yang akan terjadi membuat setiap orang lebih mempersiapkan segala sesuatu, baik untuk kehidupan manusia maupun harta benda yang dimiliki. Seiring perkembangan teknologi, maka berbagai model juga prediksi mengalami banyak kemajuan yang cukup pesat (Sari, 2016). Menurut Nursakinah Aulia Fitri., 2020 Backpropagation dapat menjamin tingkat keakuratan yang baik dalam melakukan prediksi dengan jumlah data yang besar sebab, pada backpropagation dapat dilakukan optimisasi pada jumlah jaringan tersembunyi, jumlah neuron dan jumlah data masukan pada data latih secara bebas. Oleh sebab itu Salah satu metode yang dapat digunakan untuk memprediksi adalah metode backpropagation.

Penelitian sebelumnya yang dilakukan oleh Ayu Artika Fardhani,dkk (2018) berjudul "Prediksi Harga Eceran Beras Di Pasar Tradisional Di 33 Kota Di Indonesia Menggunakan Algoritma Backpropagation" dengan learning rate 0.09 dapat melakukan prediksi dengan akurasi $88 \%$, dengan demikian metode backpropagation dapat digunakan untuk memprediksi harga beras. Berdasarkan uraian diatas penulis akan melakukan penelitian untuk memprediksi harga beras pada tingkat perdagangan besar di Indonesia dengan learning rate 0,25 , dan struktur jaringan yang digunakan terdiri dari 5 neuron input, 10 neuron lapisan tersembunyi dan 1 neuron lapisan input dengan menggunakan metode algoritma backpropagation dengan nilai epoch 1500 . Untuk menghitung tingkat akurasi menggunakan metode MAPE. Data yang digunakan dalam penelitian ini merupakan data ratarata harga beras bulanan di tingkat perdagangan besar dari bulan Januari 2010 - Desember 2020 dalam bentuk Rp/Kg. Penelitian ini menggunakan data yang diperoleh dari website BPS Indonesia pada Tahun 2010-2020.

\section{METODE PENELITIAN}

Lokasi pengolahan data dilakukan di Laboratorium Komputer Jurusan Matematika Fakultas Matematika dan IImu Pengetahuan Alam, Universitas Tadulako. Sumber data yang digunakan 
merupakan data sekunder yaitu berupa data harga beras di tingkat perdagangan besar indonesia yang diperoleh dari link resmi https://www.bps.go.id/indicator/20/295/1/rata-rata-harga-beras-di-tingkatperdagangan-besar-grosir-indonesia. Jenis data yang digunakan adalah data kuantitatif yaitu data harga beras dalam kurun waktu 11 tahun terakhir yaitu dari tahun 2010 - 2020.

\section{HASIL DAN PEMBAHASAN}

\subsection{Hasil}

Data yang digunakan dalam penelitian ini diperoleh dari website BPS Indonesia dan data yang digunakan adalah data jumlah rata-rata harga beras di tingkat perdagangan besar Indonesia dari tahun 2010-2020. Data harga beras yang di peroleh sebanyak 132 data yang diambil dari tahun 2010-2020. Data dibagi menjadi 2 bagian, yang pertama digunakan untuk data training dan yang kedua digunakan untuk data testing. Data training digunakan untuk membangun model arsitektur, sedangkan data testing digunakan untuk mengukur akurasi model. Data yang digunakan untuk training adalah $50 \%$ dan data testing juga $50 \%$. Data training diambil dari tahun 2010-2015 dan data testing diambil dari tahun 2015-2020.

Tabel 1 : Data Harga beras di tingkat perdagangan besar dari tahun 2010-2020

\begin{tabular}{|c|c|c|c|c|c|c|c|c|c|c|c|c|}
\hline \multirow{2}{*}{ No } & \multirow{2}{*}{ Bulan } & \multicolumn{10}{|c|}{ Tahun } \\
\cline { 3 - 13 } & & 2010 & 2011 & 2012 & 2013 & 2014 & 2015 & 2016 & 2017 & 2018 & 2019 & 2020 \\
\hline 1 & Januari & 6.702 & 7.853 & 8.726 & 8.835 & 9.433 & 10.612 & 11.614 & 11.579 & 12.276 & 12.211 & 12.343 \\
\hline 2 & Februari & 6.888 & 7.612 & 8.778 & 8.843 & 9.531 & 10.766 & 11.729 & 11.571 & 11.414 & 12.222 & 12.355 \\
\hline 3 & Maret & 6.854 & 7.371 & 8.687 & 8.783 & 9.596 & 10.987 & 11.678 & 11.494 & 12.299 & 12.124 & 12.368 \\
\hline 4 & April & 6.761 & 7.199 & 8.583 & 8.711 & 9.425 & 10.648 & 11.499 & 11.449 & 12.035 & 12.019 & 12.382 \\
\hline 5 & Mei & 6.772 & 7.233 & 8.537 & 8.681 & 9.414 & 10.569 & 11.417 & 11.465 & 11.943 & 12.008 & 12.293 \\
\hline 6 & Juni & 6.873 & 7.463 & 8.554 & 8.784 & 9.462 & 10.679 & 11.469 & 11.465 & 11.907 & 12.009 & 12.224 \\
\hline 7 & Juli & 7.026 & 7.899 & 8.606 & 9.018 & 9.525 & 10.732 & 11.498 & 11.448 & 11.936 & 12.021 & 12.213 \\
\hline 8 & Agustus & 7.318 & 8.152 & 8.635 & 9.057 & 9.525 & 10.935 & 11.475 & 11.411 & 11.899 & 12.018 & 12.212 \\
\hline 9 & September & 7.351 & 8.255 & 8.624 & 9.058 & 9.694 & 11.055 & 11.448 & 11.482 & 11.9 & 12.05 & 12.182 \\
\hline 10 & Oktober & 7.391 & 8.416 & 8.624 & 9.108 & 9.781 & 11.169 & 11.433 & 11.552 & 11.926 & 12.108 & 12.187 \\
\hline 11 & November & 7.457 & 8.496 & 8.655 & 9.152 & 9.924 & 11.365 & 11.45 & 11.665 & 12.013 & 12.12 & 12.179 \\
\hline 12 & Desember & 7.617 & 8.726 & 8.702 & 9.262 & 10.344 & 11.465 & 11.476 & 11.838 & 12.106 & 12.184 & 12.185 \\
\hline
\end{tabular}

Sumber:https://www.bps.go.id/indicator/20/295/1/rata-rata-harga-beras-di-tingkat-perdagangan-

besar-grosir-indonesia

\subsubsection{Normalisasi Data}

Sebelum data training dan data testing diolah menggunkan algoritma backpropagation, data tersebut harus dinormalisasikan. Normalisasi pada penelitian ini menggunakan normalisasi sigmoid. Hasil normalisasi untuk data training dapat dilihat pada Tabel 2. Normalisasi pada penelitian ini menggunakan Microsoft excel. Berikut adalah persamaan yang digunakan untuk menormalisasi data:

$$
x^{\prime}=\frac{0,8(X-\operatorname{Min})}{\operatorname{Max}-\operatorname{Min}}+0,1
$$


Tabel 2 : Normalisasi data training

\begin{tabular}{|c|c|c|c|c|c|c|c|}
\hline \multirow{2}{*}{ No } & \multirow{2}{*}{ Bulan } & \multicolumn{7}{|c|}{ Tahun } \\
\cline { 3 - 7 } & & 2010 & 2011 & 2012 & 2013 & 2014 & 2015 \\
\hline 1 & Januari & 0.10000 & 0.29332 & 0.43995 & 0.45826 & 0.55870 & 0.75673 \\
\hline 2 & Februari & 0.13124 & 0.25284 & 0.44869 & 0.45961 & 0.57516 & 0.78260 \\
\hline 3 & Maret & 0.12553 & 0.21237 & 0.43340 & 0.44953 & 0.58608 & 0.81971 \\
\hline 4 & April & 0.10991 & 0.18348 & 0.41594 & 0.43743 & 0.55736 & 0.76278 \\
\hline 5 & Mei & 0.11176 & 0.18919 & 0.40821 & 0.43240 & 0.55551 & 0.74951 \\
\hline 6 & Juni & 0.12872 & 0.22782 & 0.41106 & 0.44970 & 0.56357 & 0.76798 \\
\hline 7 & Juli & 0.15442 & 0.30105 & 0.41980 & 0.48900 & 0.57415 & 0.77688 \\
\hline 8 & Agustus & 0.20346 & 0.34354 & 0.42467 & 0.49555 & 0.57415 & 0.81098 \\
\hline 9 & September & 0.20901 & 0.36084 & 0.42282 & 0.49572 & 0.60254 & 0.83114 \\
\hline 10 & Oktober & 0.21573 & 0.38789 & 0.42282 & 0.50412 & 0.61715 & 0.85028 \\
\hline 11 & November & 0.22681 & 0.40132 & 0.42803 & 0.51151 & 0.64117 & 0.88320 \\
\hline 12 & Desember & 0.25368 & 0.43995 & 0.43592 & 0.52998 & 0.71172 & 0.90000 \\
\hline
\end{tabular}

Tabel 3 : Normalisasi data Testing

\begin{tabular}{|c|c|c|c|c|c|c|c|}
\hline \multirow{2}{*}{ No } & \multirow{2}{*}{ Bulan } & \multicolumn{6}{|c|}{ Tahun } \\
\cline { 3 - 7 } & & 2015 & 2016 & 2017 & 2018 & 2019 & 2020 \\
\hline 1 & Januari & 0.11897 & 0.56111 & 0.54567 & 0.85323 & 0.82454 & 0.88279 \\
\hline 2 & Februari & 0.18693 & 0.61186 & 0.54214 & 0.47286 & 0.82940 & 0.88809 \\
\hline 3 & Maret & 0.28445 & 0.58935 & 0.50816 & 0.86338 & 0.78616 & 0.89382 \\
\hline 4 & April & 0.13486 & 0.51037 & 0.48831 & 0.74688 & 0.73982 & 0.90000 \\
\hline 5 & Mei & 0.10000 & 0.47419 & 0.49537 & 0.70629 & 0.73497 & 0.86073 \\
\hline 6 & Juni & 0.14854 & 0.49713 & 0.49537 & 0.69040 & 0.73541 & 0.83028 \\
\hline 7 & Juli & 0.17192 & 0.50993 & 0.48787 & 0.70320 & 0.74071 & 0.82543 \\
\hline 8 & Agustus & 0.26150 & 0.49978 & 0.47154 & 0.68687 & 0.73938 & 0.82499 \\
\hline 9 & September & 0.31445 & 0.48787 & 0.50287 & 0.68731 & 0.75350 & 0.81175 \\
\hline 10 & Oktober & 0.36475 & 0.48125 & 0.53376 & 0.69879 & 0.77910 & 0.81395 \\
\hline 11 & November & 0.45124 & 0.48875 & 0.58362 & 0.73718 & 0.78439 & 0.81042 \\
\hline 12 & Desember & 0.49537 & 0.50022 & 0.65996 & 0.77821 & 0.81263 & 0.81307 \\
\hline
\end{tabular}

\subsubsection{Perancangan Asitektur}

Pada jaringan syaraf tiruan, neuron-neuron akan dikumpulkan dalam sebuah lapisan yang disebut dengan neuron (neuron layer). Neuron-neuron pada satu lapisan akan dihubungkan dengan lapisan-lapisan lainnya. Pada jaringan syaraf tiruan hubungan ini dikenal dengan nama bobot dan bias. Adapun arsitektur yang digunakan dalam penelitian ini adalah pada Gambar 1. 


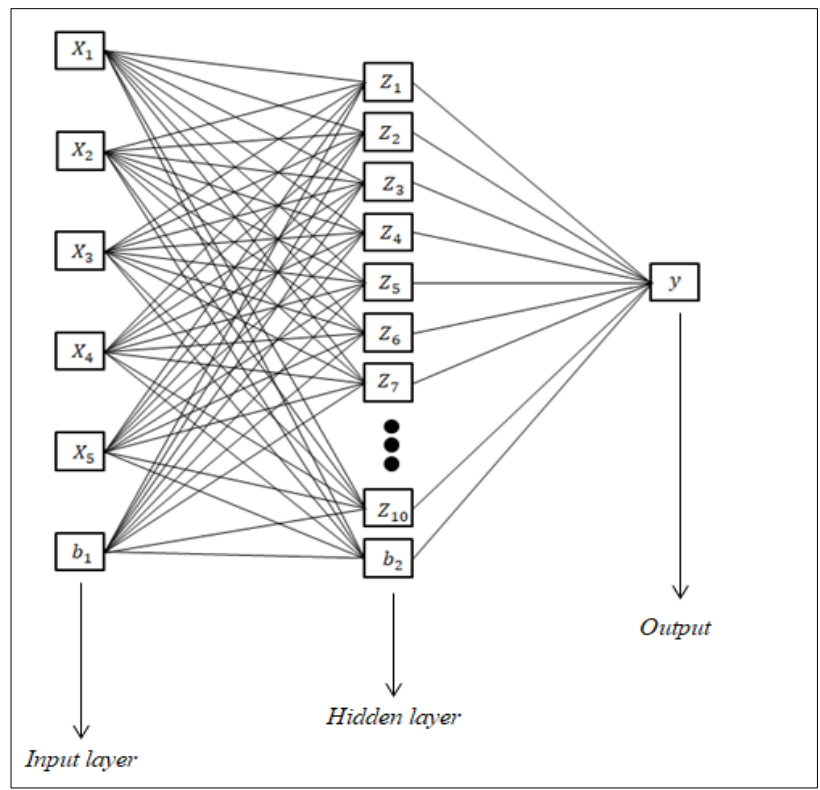

Gambar 1 : Arsitektur Jaringan Syaraf Tiruan

\subsubsection{Pengolahan Data Menggunakan Matlab Dengan Metode Backpropagation}

a. Data Training

Pelatihan data digunakan untuk membangun model jaringan. Sebelum training dilakukan terlebih dahulu ditentukan nilai parameter yang diinginkan guna memperoleh hasil yang diinginkan. Untuk proses training tersebut kita menggunakan aplikasi Matlab dan menggunakan syntax sebagai berikut:

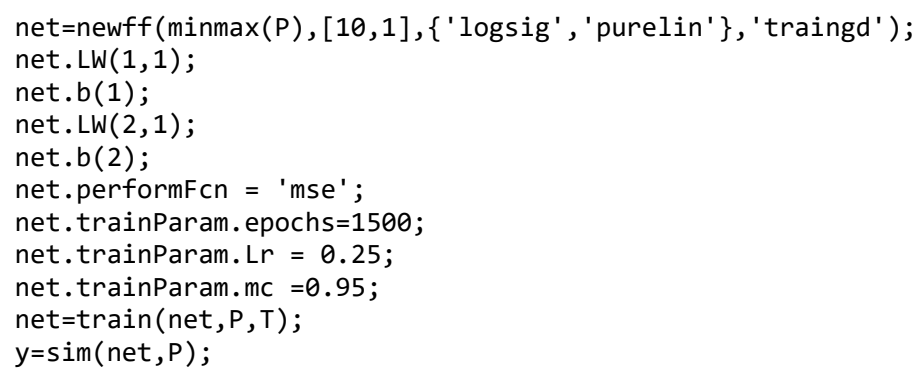

sehingga proses training dapat dilihat pada Gambar 2 . 


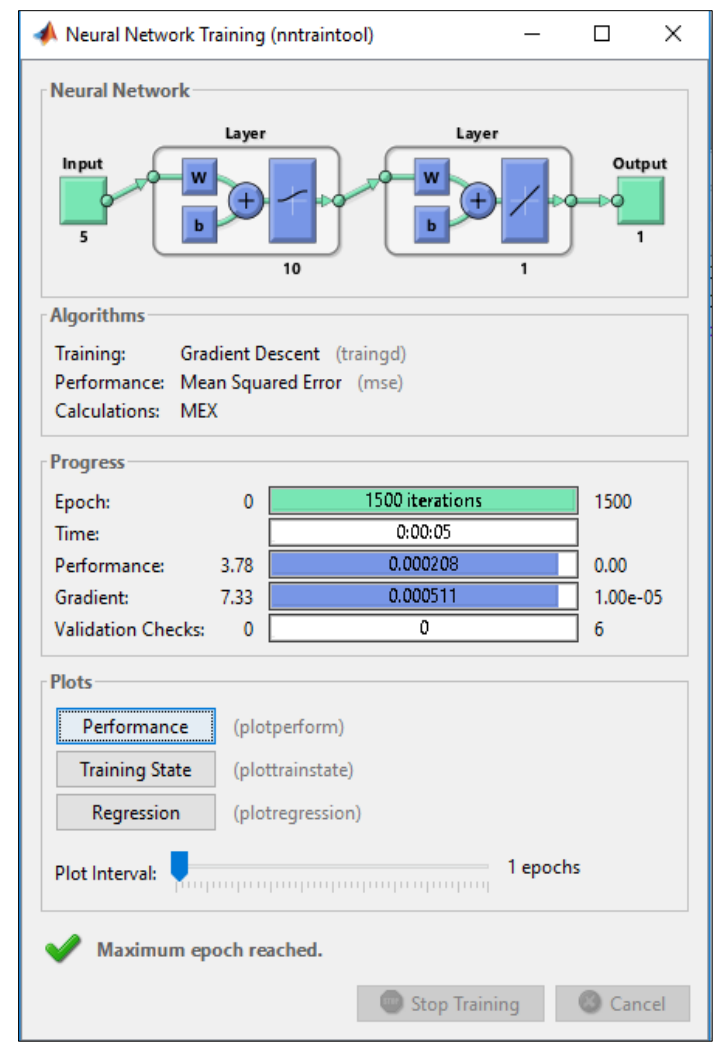

Gambar 2 : Proses pelatihan data pada matlab 2016

Pada Tabel 4 memperlihatkan nilai MAPE dari data training.

Tabel 4 : Nilai Mape data trining

\begin{tabular}{|c|c|c|c|c|c|c|}
\hline No & Target & Output & Error & MAPE & $\begin{array}{c}\text { Learning } \\
\text { Rate }\end{array}$ & Epoch \\
\hline 1 & 0.75673 & 0.753063 & 0.00367 & 0.00485 & 0,25 & 1500 \\
\hline 2 & 0.78260 & 0.787803 & 0.00520 & 0.00665 & 0,25 & 1500 \\
\hline 3 & 0.81971 & 0.816399 & 0.00331 & 0.00404 & 0,25 & 1500 \\
\hline 4 & 0.76278 & 0.756517 & 0.00626 & 0.00821 & 0,25 & 1500 \\
\hline 5 & 0.74951 & 0.75816 & 0.00865 & 0.01154 & 0,25 & 1500 \\
\hline 6 & 0.76798 & 0.76765 & 0.00033 & 0.00043 & 0,25 & 1500 \\
\hline 7 & 0.77688 & 0.773714 & 0.00317 & 0.00407 & 0,25 & 1500 \\
\hline 8 & 0.81098 & 0.819697 & 0.00872 & 0.01075 & 0,25 & 1500 \\
\hline 9 & 0.83114 & 0.833001 & 0.00186 & 0.00224 & 0,25 & 1500 \\
\hline 10 & 0.85028 & 0.845741 & 0.00454 & 0.00534 & 0,25 & 1500 \\
\hline 11 & 0.8832 & 0.878676 & 0.00452 & 0.00512 & 0,25 & 1500 \\
\hline 12 & 0.9 & 0.901911 & 0.00191 & 0.00212 & 0,25 & 1500 \\
\hline & & & & 0.06536 & & \\
\hline & & & & 12 & & \\
\hline
\end{tabular}




\begin{tabular}{|l|l|l|l|l|l|l|}
\hline & & & & 0.00545 & & \\
\hline & & & & $0.54467 \%$ & & \\
\hline
\end{tabular}

Keberhasilan proses training dapat dilihat dari tabel 5. tabel tersebut memperlihatkan nilai MAPE dari masing-masing arsitektur.

Tabel 5 : Hasil Perbandingan 4 Arsitektur

\begin{tabular}{|c|c|c|c|c|c|}
\hline No & Arsitektur & Epoch & Learning rate & Waktu & MAPE \\
\hline \multirow{12}{*}{1} & \multirow{12}{*}{$5-5-1$} & \multirow{3}{*}{500} & 0,1 & 00:02 & $2.33299 \%$ \\
\hline & & & 0,25 & $00: 02$ & $4.07176 \%$ \\
\hline & & & 0,5 & 00:02 & $1.42094 \%$ \\
\hline & & \multirow{3}{*}{1000} & 0,1 & 00:04 & $1.96416 \%$ \\
\hline & & & 0,25 & 00:04 & $2.26356 \%$ \\
\hline & & & 0,5 & 00:04 & $1.80820 \%$ \\
\hline & & \multirow{3}{*}{1500} & 0,1 & 00:05 & $2.41716 \%$ \\
\hline & & & 0,25 & 00:06 & $2.04269 \%$ \\
\hline & & & 0,5 & 00:05 & $1.69461 \%$ \\
\hline & & \multirow{3}{*}{2000} & 0,1 & 00:07 & $3.13201 \%$ \\
\hline & & & 0,25 & $00: 07$ & $1.40849 \%$ \\
\hline & & & 0,5 & 00:08 & $2.33112 \%$ \\
\hline \multirow{12}{*}{2} & \multirow{12}{*}{$5-10-1$} & \multirow{3}{*}{500} & 0,1 & $00: 13$ & $4.65544 \%$ \\
\hline & & & 0,25 & 00:02 & $2.99954 \%$ \\
\hline & & & 0,5 & 00:02 & $3.70268 \%$ \\
\hline & & \multirow{3}{*}{1000} & 0,1 & 4 & $2.05363 \%$ \\
\hline & & & 0,25 & 00:04 & $1.39560 \%$ \\
\hline & & & 0,5 & $00: 12$ & $5.64797 \%$ \\
\hline & & \multirow{3}{*}{1500} & 0,1 & 00:06 & $4.09388 \%$ \\
\hline & & & 0,25 & 00:05 & $0.54467 \%$ \\
\hline & & & 0,5 & 00:05 & $3.31280 \%$ \\
\hline & & \multirow{3}{*}{2000} & 0,1 & 00:08 & $1.42505 \%$ \\
\hline & & & 0,25 & $00: 07$ & $1.15296 \%$ \\
\hline & & & 0,5 & 00:08 & $1.71538 \%$ \\
\hline \multirow{3}{*}{3} & \multirow{3}{*}{$5-25-1$} & \multirow{3}{*}{500} & 0,1 & 00:02 & $4.73958 \%$ \\
\hline & & & 0,25 & 00:03 & $4.68123 \%$ \\
\hline & & & 0,5 & 00:02 & $5.45953 \%$ \\
\hline
\end{tabular}




\begin{tabular}{|c|c|c|c|c|c|}
\hline & & \multirow{3}{*}{1000} & 0,1 & 00:05 & $4.24267 \%$ \\
\hline & & & 0,25 & 00:04 & $2.86067 \%$ \\
\hline & & & 0,5 & 00:05 & $4.70361 \%$ \\
\hline & & \multirow{3}{*}{1500} & 0,1 & 00:06 & $1.19289 \%$ \\
\hline & & & 0,25 & 00:06 & $5.11080 \%$ \\
\hline & & & 0,5 & 00:06 & $4.70098 \%$ \\
\hline & & \multirow{3}{*}{2000} & 0,1 & $00: 11$ & $1.72886 \%$ \\
\hline & & & 0,25 & 00:08 & $2.74067 \%$ \\
\hline & & & 0,5 & 00:08 & $4.68288 \%$ \\
\hline \multirow{12}{*}{4} & \multirow{12}{*}{$5-30-1$} & \multirow{3}{*}{500} & 0,1 & 00:02 & $2.79713 \%$ \\
\hline & & & 0,25 & 00:02 & $3.91794 \%$ \\
\hline & & & 0,5 & 00:02 & $5.13921 \%$ \\
\hline & & \multirow{3}{*}{1000} & 0,1 & 00:04 & $4.94565 \%$ \\
\hline & & & 0,25 & 00:04 & $4.97516 \%$ \\
\hline & & & 0,5 & 00:05 & $5.10993 \%$ \\
\hline & & \multirow{3}{*}{1500} & 0,1 & 00:06 & $1.93943 \%$ \\
\hline & & & 0,25 & 00:06 & $3.72090 \%$ \\
\hline & & & 0,5 & 00:06 & $5.06909 \%$ \\
\hline & & \multirow{3}{*}{2000} & 0,1 & 00:08 & $1.13658 \%$ \\
\hline & & & 0,25 & 00:08 & $3.42569 \%$ \\
\hline & & & 0,5 & $00: 17$ & $4.08433 \%$ \\
\hline \multirow{12}{*}{5} & \multirow{12}{*}{ 5-50-1 } & \multirow{3}{*}{500} & 0,1 & 00:02 & $5.84309 \%$ \\
\hline & & & 0,25 & 00:02 & $6.55689 \%$ \\
\hline & & & 0,5 & 00:02 & $5.42901 \%$ \\
\hline & & \multirow{3}{*}{1000} & 0,1 & $00: 14$ & $7.48468 \%$ \\
\hline & & & 0,25 & 00:04 & $5.45781 \%$ \\
\hline & & & 0,5 & 00:07 & $5.08406 \%$ \\
\hline & & \multirow{3}{*}{1500} & 0,1 & 00:07 & $2.10507 \%$ \\
\hline & & & 0,25 & 00:06 & $5.10048 \%$ \\
\hline & & & 0,5 & 00:06 & $4.86617 \%$ \\
\hline & & \multirow{3}{*}{2000} & 0,1 & 00:09 & $3.59462 \%$ \\
\hline & & & 0,25 & 00:09 & $5.17079 \%$ \\
\hline & & & 0,5 & 00:09 & $4.42047 \%$ \\
\hline
\end{tabular}


Dari Tabel 5 dapat dilihat model arsitektur terbaik adalah 5-10-1 yaitu 5 neuron input, 10 neuron lapisan tersembunyi dan 1 neuron lapisan input dengan epoch sebesar 1500 iterasi dan waktu 00:05 detik, dimana tingkat epoch dan waktu diperoleh menggunakan aplikasi Matlab sedangkan MAPE diperoleh dengan menggunakan perhitungan Microsoft excel.

\section{b. Data Testing}

Pengujian data merupakan tahapan dimana system mulai melakukan proses prediksi harga beras. Input data yang digunakan dalam proses training adalah data dari tahun 2015-2020. Pengujian dilakukan dengan menggunakan rancangan arsitektur terbaik yang diperoleh dari hasil pelatihan data. Struktur jaringan yang digunakan terdiri dari 5 neuron input, 10 neuron lapisan tersembunyi dan 1 neuron lapisan input. Proses training tersebut menggunakan fungsi aktifasi sigmoid biner (logsig) dan fungsi identitas (purelin), seperti pada Gambar 3.

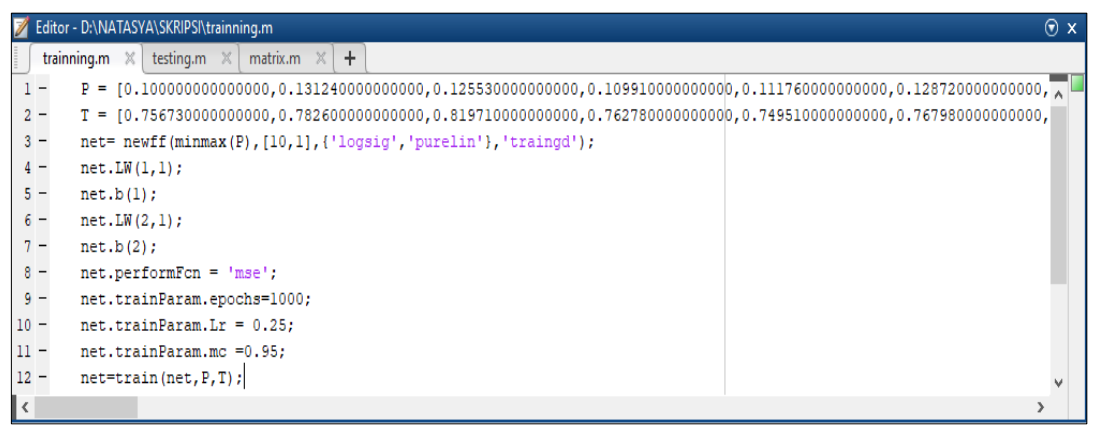

Gambar 3 : Pengguaan fungsi aktifasi pada program matlab 2016

Hasil pengujian data pada program matlab 2016 menggunakan arsitektur yang telah didapat dari hasil pelatihan dapat dilihat di Tabel 6.

Tabel 6 : Hasil Pengujian pengujian prediksi dan perbandingan prediksi data aktual.

\begin{tabular}{|c|c|c|c|}
\hline Bulan & Data Aktual(2020) & Prediksi (2020) & MAPE \\
\hline Januari & 12,343 & 12,378 & 0.00056 \\
\hline Februari & 12,355 & 12,379 & 0.00032 \\
\hline Maret & 12,368 & 12,380 & 0.00028 \\
\hline April & 12,382 & 12,383 & 0.00374 \\
\hline Mei & 12,293 & 12,374 & 0.00687 \\
\hline Juni & 12,224 & 12,361 & 0.01361 \\
\hline Juli & 12,213 & 12,362 & 0.00316 \\
\hline Agustus & 12,212 & 12,366 & 0.01459 \\
\hline September & 12,182 & 12,358 & 0.00796 \\
\hline Oktober & 12,187 & 12,360 & 0.00142 \\
\hline
\end{tabular}




\begin{tabular}{|c|c|c|c|}
\hline November & 12,179 & 12,359 & 0.00039 \\
\hline Desember & 12,185 & 12,360 & 0.00023 \\
\hline \multicolumn{2}{|c|}{ Rata-rata MAPE } & $0.44 \%$ \\
\hline
\end{tabular}

Dari Tabel 6 dapat dilihat rata-rata nilai MAPE hasil simulasi prediksi harga beras menggunakan aplikasi MATLAB pada tahun 2020 dari bulan Januari - Desember adalah sebesar $0,44 \%$.

\subsection{Pembahasan}

Data dari penelitian ini diperoleh dari data harga beras dari bulan Januari 2010 Desember 2020. Proses prediksi diawali dengan membangun arsitektur jaringan menggunakan data training yang datanya menggunakan data tahun 2010-2015, sebelum perancangan arsitektur data dinormalisasi terlebih dahulu agar jaringan tidak mengalami kegagalan dalam melakukan pembelajaran. Diambil 5 arsitektur berbeda dengan nilai epoch sebesar 200, 100 , 1500,2000 dan learning rate yang berbeda yaitu 0,1,0,25,0,5. Nilai MAPE dari model arsitektur 5-10-1 learning rate 0,25 dan epoch sebanyak 1500 memperoleh nilai mape terkecil dari semua model arsitektur yaitu $0,54467 \%$ jika dilihat dari kriteria MAPE hal ini menunjukan bahwa kemampuan prediksi sangat baik karena nilainya dibawah $10 \%$ sehingga arsitektur 5-10-1 merupakan model arsitektur terbaik yang akan digunakan untuk menghitung data testing dan data peramalan. kemudian dilanjutkan dengan menguji arsitektur yang dibentuk dari proses training menggunakan data testing yang datanya menggunakan data tahun 2015-2020 dan diperoleh hasil prediksi yang tidak jauh berbeda dengan data asli hal ini menunjukan bahwa arsitektur 5-10-1 merupan arsitektur terbaik yang dapat digunakan untuk memprediksi harga beras di tingkat perdagangan besar Indonesia pada tahun 2021.

Setelah itu penulis melakukan prediksi menggunakan arsitektur terbaik. Dari hasil prediksi harga beras untuk tahun 2021 yang tingkat akurasi menggunakan MAPE mencapai $1,02 \%$,dari hasil prediksi didapatkan hasil prediksi seperti pada Tabel 7 , dari pengamatan penulis terjadi penurunan harga di setiap bulannya.

Tabel 7 : Prediksi harga beras tahun 2021

\begin{tabular}{|c|c|c|}
\hline & Prediksi (2021) & Data Aktual (2021) \\
\hline Januari & 12,372 & 12.186 \\
\hline Februari & 12,376 & 12.191 \\
\hline Maret & 12,380 & 12.127 \\
\hline April & 12,383 & - \\
\hline Mei & 12,362 & - \\
\hline Juni & 12,343 & - \\
\hline
\end{tabular}




\begin{tabular}{|c|l|l|}
\hline Juli & 12,352 & - \\
\hline Agustus & 12,349 & - \\
\hline September & 12,338 & - \\
\hline Oktober & 12,343 & - \\
\hline November & 12,339 & - \\
\hline Desember & 12,342 & - \\
\hline
\end{tabular}

IV. KESIMPULAN

Berdasarkan penelitian yang dilakukan dapat disimpulkan bahwa:

1. Hasil prediksi harga beras di tingkat perdagangan besar Indonesia dengan menggunakan metode backpropagation adalah pada bulan Januari 2021 Rp.12,372, Februari Rp.12,376, Maret Rp.12,380, April Rp.12,383,Mei Rp.12,362, Juni Rp12,343, Juli Rp.12,352,Agustus Rp.12,349,September Rp.12,338, Oktober Rp.12,343, November Rp.12,339, Desember Rp.12,342. Rata-rata harga beras mengalami penurunan harga disetiap bulannya.

2. Penerapan metode backpropagation untuk prediksi harga beras di tingkat perdagangan besar Indonesia dengan algoritma backpropagation dapat bekerja dengan baik. Dengan arsitektur 5-10-1 dan learning rate 0.25. Tingkat akurasi dari prediksi menggunakan metode backpropagation pada data training dari tahun $2010-2015$ mencapai $0.54467 \%$ dan tingkat akurasi dari prediksi menggunakan metode backpropagation pada data testing dari tahun 20152020 mencapai $0,44262 \%$

\section{DAFTAR PUSTAKA}

[1]. Andrian, Y., \& Ningsih, E., Prediksi Curah Hujan Di Kota Medan Menggunakan Metode Backpropagation Neural Network. Seminar Nasional Informatika, 2014,184-189.

[2]. Astia, R. Y., Santony, J., \& Sumijan, S., Prediction Of Amount Of Use Of Planning Family Contraception Equipment Using Monte Carlo Method (Case Study In Linggo Sari Baganti District). Indonesian Journal of Artificial Intelligence and Data Mining, 2019, 2(1), 28-36. https://doi.org/10.24014/ijaidm.v2i1.5825

[3]. Fardhani, A. A., Simanjuntak, D. I. N., \& Wanto, A., Prediksi Harga Eceran Beras Di Pasar Tradisional Di 33 Kota Di Indonesia Menggunakan Algoritma Backpropagation. Jurnal Infomedia, 2018, 3(1). https://doi.org/10.30811/jim.v3i1.625

[4]. kholis, I., \& Rofii, A., Analisis Variasi Parameter Backpropagation Artificial Neural Network Pada Sistem Pengenalan Wajah Berbasis Principal Component Analysis. Jurnal Kajian Teknik Elektro, 2017, 2(1), 1-12.

[5]. Maricar, M. A., Analisa Perbandingan Nilai Akurasi Moving Average dan Exponential Smoothing untuk Sistem Peramalan Pendapatan pada Perusahaan XYZ. Jurnal Sistem 
Dan Informatika, 2019, 13(2), 36-45.

[6]. Nursakinah Aulia Fitri, I. T., Perbandingan JST Metode Backpropagation dan Metode Radial Basis dalam Memprediksi Curah Hujan Harian Bandara Internasional Minangkabau, 2020, $9(2)$.

[7]. Restoran, D. A. N., Kebijakan, P., \& Makro, E., Laporan Tim Kajian Profil Sektor Riil : Sektor Perdagangan , HOTEL , 2012.

[8]. Sari, Y. N., Untuk Memprediksi Luas Area Serangan, 2016.

[9]. Wibowo, A. B., \& Rukmayadi, D., P-66 Pengendalian Persedian Bahan Baku Dengan Metode Material Requirement Planning (MRP) Untuk Produk Kue Di Perusahaan " $Q$ " Control Of Raw Material Inventories Using Material Requirement Planning ( MRP) Method For Cake Products In, 2020. 